\title{
Success Factors for Local Development Project Management Case of Taroudant Province - Morocco
}

\author{
Ouafa Barakat ${ }^{1}$, Abdelaziz Bendou ${ }^{2}$ and Juan Carlos Martin ${ }^{3}$ \\ ${ }^{1,2}$ National School of commerce and Management, University Ibn Zohr, \\ Agadir, Morocco \\ ${ }^{3}$ University of Las Palmas de Gran Canaria
}

Correspondence should be addressed to: Ouafaa Barakat;

Received date: 15 July 2014; Accepted date: 24 September 2014; Published date: 16 March 2015

Copyright $@$ 2015. Ouafa BARAKAT, Abdelaziz BENDOU and Juan Carlos MARTIN. Distributed under Creative Commons CC-BY 4.0

\begin{abstract}
The project development management success presents an ongoing challenge for managers. It is perceived as a means allowing to meet the effectiveness and efficiency challenges in complex and unstable environment. The purpose of this paper is to explore from different perspectives of the local players looking at the key success factors that can contribute to the local development project management success. According to Lim and M Zain (1999), success factors are defined as a set of circumstances, facts, or influences that lead to a result. However, very few researches worked on development project management success factors, and most of them lacked precision in the subject matter.Using local development project of Taroudant province (located in south of Morocco) as a case study, this paper explores the factors that seem to contribute to project management success. The latter have been classified into four categories: (1) factors related to the manager and the project team, (2) organizational factors, (3) factors related to the project, (4) factors related to the external environment. Our objective is to understand the degree of importance of these factors in the project lifecycle from the perspective of local players.The data collected was analyzed using thematic content analysis. Results indicated that all factors are found to be vital in achieving the project management success. It was also revealed that the relative importance of these factors varies significantly at different phases of project lifecycle.
\end{abstract}

Keywords: project management, key success factors, local development project, project success.

\section{Introduction}

Several approaches and theories developed over the years depend to the human development concept. This concept has gone through certain chronological evolution rather rich in surrounding areas of development (Legouté, 2001; Pecqueur, 2000, 2005 ; Tremblay, 1999). The succession of the economic approach, the sectoral approach, the integrated approach, participative approach, etc translate logic 
and viable complement to answer better the evolution of the local and international context.

The importance of local dimension and its implication in development policies knew a significant evolution. It reflects the change in the know how in development implementation approach, which became a fundamental base to overcome poverty and improve a sustainable life standards.

However, the problem of project development success in achieving human development or development targets is still at stake. Despite the ambitious goals set by these projects several socioeconomic problems still significant. There are characterized by high rates of poverty, precariousness, vulnerability and social exclusion. Hence, these projects development were not able to solve problems for which they emitted. Difficulties of development policy sustainability and limits of territorial strategic planning did not take into account the local population needs.

This ineffectiveness is also understandable by the report of the existence of numerous deficiencies of managerial nature: the bad project conception, the divergence of expectations and perspectives of the stakeholders, the non compliance with the dead-lines of the projects, and so forth (Ika, 2007).

According to Ika (2005a), the high rate of project development failure is essentially due to the problems of project management, which settles more particularly in the conception phase. The specific of the project development character, requires the use of success factors by project managers. It turns out to be a necessity to ensure good chances of their project success (Pinto \& Slevin, 1988). In addition, research by Turner (2004), affirms also that if the success factors are adequately identified and applied, the chance of a successful project will be greatly increased.

Jugdev and Muller (2005; p. 24), defined success factors as "elements required to create an environment where projects are managed consistently with excellence".

According to the project management literature, there are several definitions of key success factors that vary from one author to another. The key success factors can be understood as the conditions where things must go right for the successful project implementation process.

The present study is within the framework of the project entitled: "The Realization of the participative territorial diagnostic and the support of the elaboration of communal plan to develop 66 communes within Taroudant province". The project will contribute to the general strategic main directions of the government in case of decentralization. Indeed, this approach mobilizes local communities by transferring responsibilities, skills, and capabilities in order to promote their locality.

Within this new context, the local communities are called on to become an essential decision-maker and main partner in the sustainable development process and are supposed to carry out a communal development plan (CDP). This plan involves the local players committed to formulating and endorsing developmental projects in a given period of time so as to promote the local development and improve the livelihood of the local population which affected directly or indirectly by development interventions. In fact, the CDP designs local development through necessary means focused on carrying out projects that best suit a strategic planning that is linked to several axes of which access to basic services is an important component.

In an attempt to explore the factors that allow to local development project management to be successful in the practical context, data have been collected through semi-structured interview. We conducted eight interviews with local players from Taroudant province during April-Mai 2013. The need to further understand and establish comprehensive knowledge about the success factors of 
local development project management is what motivates this study. Consequently, the main research question of this study is: what are the factors that can help managers manage the development project more efficiently?.

The organization of the paper is as follow: Firstly, we will review the literature on the project success and factors affecting project success. Secondly, we present the research methodology. The next section is devoted to present the results of the study. Our results tend to identify the interviewee's perception to the most important factors that can ensure successful project management.

\section{Literature review and methodological framework}

The review of this section is divided into two parts. The first part is related to literature review on project success, and key success factors. The second part, will discuss the research methodology and data collection methods as directions to finding the answers for the main research question of our study.

\section{Literature review}

\section{Project Success}

The project success is one of the rich and most discussed concept in project management literature. It has attracted the attention of many researchers and practitioners. Is the most important preoccupation (Cooke-Davies, 2002) and a large motivator in the outcome of any project (Bérubé \& Noël, 2011). The project success concept poses significant challenges, and wide divergence on what project success means. There is no uniform measure to what constitutes project success.

As mentioned by Liu and Walker (1998; p. 213), "Project success is a topic that is frequently discussed and yet rarely agreed upon. The project success concept has remained ambiguously defined. It is a concept which can mean so much to so many different people because of varying perceptions, and leads to disagreements about whether a project is successful or not".

There can be ambiguity in determining whether a project is a success (Belassi \& Tukel, 1996).

According to this author, there are two main reasons for this ambiguity. First, the project success can be viewed from different perspectives, which means that the same project could be perceived a success by one party and unsuccessful by another party. « [...] project success should be viewed from the different perspectives of the individual owner, developer, contractor, user, the general public, and so on. These perspective differences will explain the reason why the same project could be considered a success by one and unsuccessful by another " mentioned by (Lim \& Mohamed, 1999; p. 244). Second reason, is that success factors vary from the different literature study. There is no fixed established list of common factors.

In research study by Shenhar, Levy, and Dvir (1997), project success should be assessed based on four dimensions: project efficiency, impact on the customer, direct and business success, and preparing for the future.

For Baccarini (1999), two distinct components of project success can be identified: project management success and product success. Project management success defined along the dimension of triple constraints (time, budget, quality). Product success is concerned with the effects of the project's final product, which includes project goal, purpose (satisfaction of users' needs) and satisfaction of stakeholders' needs.

The confusion between the project success and project management success is discussed by Munns and Bjeirmi (1996). These two concepts are not directly correlated, " a project may still be successful despite the failings of project management because it meets the higher and long-term objectives" (Munns \& Bjeirmi, 1996; p. 82). 
Lim and Mohamed (1999), have a similar interpretation of looking at project success. They divide project success into macro and micro viewpoint.

However, Atkinson (1999) research does not distinguish between project success and project management success. Similar to other studies the authors agree that the time, budget and quality are the basic criteria for measuring success. While, Ika (2009), states that a classic

solution to measure project success is to propose a simple formula that can be easily applied and agreed on by parties involved.

No doubt, there is a disagreement throughout the literature in the way project success may be measured. This can be particularly problematic when the various parties who have an interest in the project have different criteria for measuring success.

\section{Key Success Factors}

The key success factors (KSF) concept has received growing interest in the project management field since 1960s. As explained by Belassi and Tukel (1996), since 1960 researchers have been concentrating on identifying factors that are critical to ensure the strategic success. The KSF are strongly related to the mission and strategic objectives of the company's project.

Many theoretical and empirical studies have provided various lists of KSF that have been developed through the literature. It varies from one author to another depending on the nature of the project, its scope, its originality, and the circumstances surrounding its implementation.

Jugdev and Muller (2005; p. 24), defined KSF as "necessary elements required to create an environment where projects are managed consistently with excellence".

According to Leidecker and Bruno (1984), the KSF correspond to the characteristics, the conditions or variables when they are followed, or managed they can have a significant impact on the firm success.

Within the literature, the KSF are those activities that need to be taken into account when managing a project. Inevitably, the KSF concept has evolved, and has been introduced in different domains. Much has been written and said about KSF, and different authors have different ways of analyzing project success factors (Ika, 2007). As mentioned by Valentin, Laura, and Delia (2013; p. 142) "some factors seem to have a universal character, appearing in several studies, while others are linked to the specific nature of the project".

In terms of international development project, the literature is relatively limited (Valentin et al., 2013). Achieving the development project management success implies a set of elements, conditions that are absolutely essential to its success. Identifying these KSFs, can help the project manager ensuring project in a well focused manner and avoid wasting effort and resources.

Diallo and Thuillier (2005), were the first authors researching the success of African international development projects, they cited in their literature criteria and KSF. Muriithi and Crawford (2003), identified three types of KSF for the development project: factors relating to the external environment of the project, factors relating to the internal environment of project, and factors appropriate to each phase of the project life cycle. Khang and Moe (2008), suggested a life-cycle based framework which measures the success criterias and success factors phase by phase. Each phase has it sets of factors. $18 \mathrm{KSF}$ are proposed.

Kwak (2002), proposed a list of 10 categories for internal and external factors that have a significant impact on international development project success. The factors have been classified into ten categories based on their nature (political, legal, cultural, technical, managerial, economical, environmental, social, corruption, and physical). 
Simard (2008), researching the success of international development projects management identified a set of KSF. These factors have a significant impact in achieving the project management success and attaining its objectives. They included factors such as local player's participation, organizational culture, manager and project team competency, and so on.

The success of a local development project depends on a set of framework conditions that need to be taking into account in the project management process. However, few studies have been conducted in this context.

The Moroccan government proposed a national guide for communal plan DGCL (2008). It defines a set of conditions, variables that can guide the project manager and the policymaker in the local development project implementation process. Also to improve the local peoples' living conditions, and empower local communities in their territories.

These conditions affect project performance at different phases of implementation. We can cite some of them:

- Conception phase: Top management support, local player's commitment, the existence of an institutional and organizational framework for the project implementation, human and financial resources ...etc.

- Planning phase: external expertise, local player's participation, and so on.

- Execution phase: effective communication plan, local players participation, capacity building of local players ...etc.

- Closedown phase: local player's participation, project monitoring and evaluation ...etc.

\section{Research Methodology}

Our field of study is a wide field, it includes 66 communes from the province of Taroudant among which 64 are rural and 2 urban. The province of Taroudant is the biggest in Morocco kingdom; it counts for $16.500 \mathrm{KM}^{2}$ surfaces among which $60 \%$ is rural zones. Its population is about 780.661 inhabitants (that is $25 \%$ of the population of the region Souss Masssa Draa) among whom $77 \%$ live in rural zones. On the physical plan, the municipalities in question are divided up between the mountains of the top and the Anti Atals and the valley of Souss with a climate of semiarid chap with an oceanic influence. 

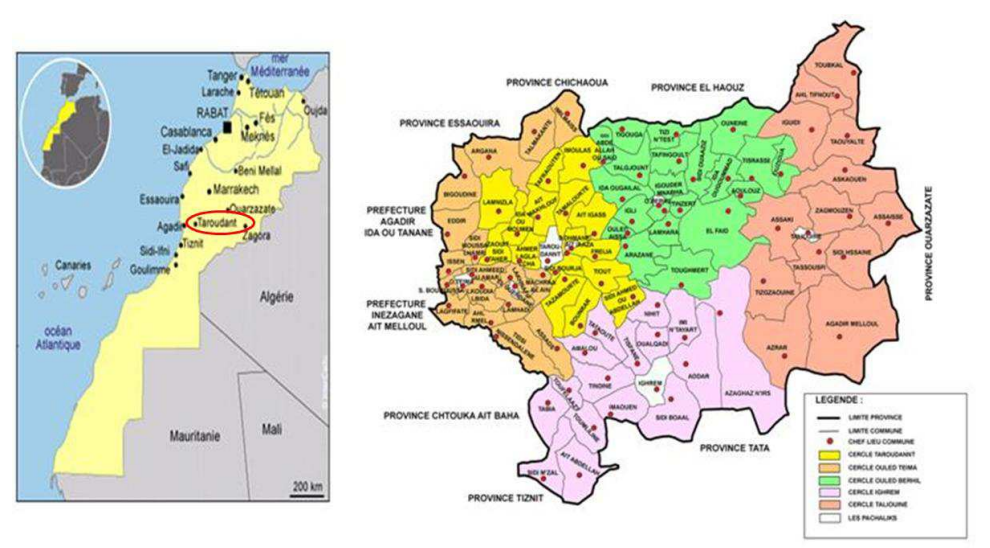

Figure 1: Localization of Taroudant province

These communes stayed outside the development like most rural areas in Morocco. The insufficiency of chronic orientation of previous public policies and other centralized development programs have caused a lack of growth in the region.
Thus, Taroudant communes are marked by an alarming social situation revealed by the main social indicators relative to poverty, and to the social and human development. This region is considered to be the poorest in the Moroccan kingdom.

Table 1: Main social indicators of the under study communes

\begin{tabular}{|l|c|c|c|}
\hline Indications & Communes & $\begin{array}{l}\text { The Taroudant } \\
\text { Province }\end{array}$ & $\begin{array}{l}\text { The Region of } \\
\text { Agadir }\end{array}$ \\
\hline Poverty rate & $22 \%$ & $22,59 \%$ & $18,60 \%$ \\
\hline Vulnerability rate & $29,6 \%$ & $21,13 \%$ & $22,6 \%$ \\
\hline Index of poverty severity & $4,6 \%$ & $3 \%$ & $2,57 \%$ \\
\hline Index of social development & $0,26 \%$ & $0,408 \%$ & $0,479 \%$ \\
\hline Index of human development & $0,39 \%$ & $0,471 \%$ & $0,601 \%$ \\
\hline
\end{tabular}

Source: Data HCP (2007) Monograph

The objective of our study is focused on understanding how local players perceive the KSF for local development of project management. The semi-structured interviews would be the most appropriate instrument, for its flexibility and the wealth of information it can generate (Miles \& Huberman, 2003). In interview studies, sample size is often justified by interviewing participants until reaching 'data saturation' (Strauss \& Corbin, 1990). However, there is no agreed method of establishing this.

Based on data saturation criterion defined by Strauss and Corbin (1990), we made eight individual interviews with local players of Taroudant province. When selecting the interviewees, it was taken into consideration their experience in project development management. All meetings were held at their work, lasting from 2 to 3 hours. An interview guide was used to structure the meetings. Openended questions, were developed based on the work of Muriithi and Crawford (2002), Khang and Moe (2008), Simard (2008) and DGCL (2008). Each of the authors work and the guide identified for each project lifecycle phase had a list of appropriate KSF.

Furthermore, we have tried to study the similarity existing between the various KSF, and derived a list of KSF. The latters, were grouped into four dimensions according to those defined by Belassi and Tukel (1996). These dimensions are: (1) 
factors related to the manager and the project team, (2) factors related to the organization, (3) factors related to the project and (4) factors related to the external environment.
The table 2 below presents the composition of our sample as well as the interviewee's characteristics:

Table 2: Sample composition

\begin{tabular}{|l|l|l|l|l|}
\hline interviewees & Gender & Age & Experience & Education level \\
\hline *RA & Male & $41-50$ & 18 years & Bac +3 \\
\hline RB & Female & $51-60$ & 16 years & Bac +5 \\
\hline RC & Male & $41-50$ & 8 years & Bac +3 \\
\hline RD & Male & $41-50$ & 14 years & Bac +5 \\
\hline RE & Male & $41-50$ & 10 years & Bac +8 \\
\hline RF & Male & $41-50$ & 15 years & Bac +5 \\
\hline RG & Male & $30-40$ & 14 years & Bac +5 \\
\hline RH & Male & $51-60$ & 18 years & Bac +2 \\
\hline
\end{tabular}

* the code which has been assigned to each respondant

\section{Results and Discussion}

In order to identify the factors perceived to be favorable to contribute to the project management success, we analyzed the viewpoints of local players interviewed.

For our data analysis and interpretation, we chose the thematic content analysis method, which is considered to be as a primary method of obtaining information from responses to open-ended question (Smith, 2000). The premise of content analysis is "that repetition of certain speech units (such as words, phrases, sentences or paragraphs) points to centres of interest and the opinions of the speakers"(Bourdon \& Kimble, 2008, p. 9).

We defined our units of analysis as groups based on thematic content as defined on our interview guide.

We now present the key results from our qualitative survey into the factors that seem to influence the success of local development project management.

Our interview guide highlights four types of factors that appear to lead to the project management success: 1) factors related to the manager and the project team members, (2) factors related to the organization, (3) factors related to the project and (4) factors related to the external environment of the project.

\section{Factors related to the project manager and project team members}

\section{Factors related to the project manager}

All the interviewees gave more importance to the skills, and professionalism of the project manager as the factors contributing to project management success. According to their own words, the meaning of leadership of the project manager, skills, qualifications are fundamental to achieve the project management success. This observation, supports the statements indicated by Khang and Moe (2008), Simard (2008), who have shown the importance of these elements in the project lifecycle phases (design, planning and execution).

Researchers Pinto and Slevin (1988), Turner and Müller (2005), Conyers and Kaul (1990), Iyer and Jha (2005), Hyvari (2006), Prabhakar (2008), Murphy and Ledwith (2007), Westerveld (2003) and Geoghegan and Dulewicz (2008), also showed that interpersonal, managerial and technical skills are key prerequisites to ensure project management success. 
The professionalism of the project manager to manage conflict is essential to ensure the project implementation success. In addition, project manager with prior experience in project management filed (administrative, technical, and financial) it is advantageous as reported by the majority of respondents. The importance of this element has also been indicated in Pakseresht and Asgari (2012), Murphy and Ledwith (2007) and Struyk (2007) research work as an important factor contributing to the project implementation effectiveness.

Project manager commitment to the project success was considered by the interviewees as an essential element throughout the project implementation process. Also, the manager commitment was judged as a key factor to achieve project goals and objectives throughout all the phases of the project lifecycle. This finding is similar to the assertions of Hyvari (2006).

Lucidity of the project goals and objectives for all parties involved in the project is an important element, which have a significant impact in planning and execution phases. All interviewees agreed that the clarification of the project scope and a clear concise definition of its objectives generate many issues that influence the success of the project management. Hence, if the project purpose and objectives have been defined and realistic in terms of impact on the local community, the various project stakeholders will be engaged and involved in the project management process.

However, without this clarification, the project aims to achieve objectives other than those provided. The writings of Pinto and Slevin (1988), Belout and Gauvreau (2004), Pinto and Prescott (1988), and Muriithi and Crawford (2003) also note the importance of this element especially in the early phases of project implementation process. Other research, Conyers and Kaul (1990), Kwak (2002), Murphy and Ledwith (2007),Clarke (1999), Al-Mashari and Zairi (1999) have also shown that a good clarification of the project purpose and objectives tends to have a high level of commitment of its stakeholders.

However, the explanations provided by the various interviewees alluded to the existence of other factors that must be considered in the project management process.

Indeed, the interviewees put an emphasis on the perfect knowledge of the project by the project manager. He should know clearly his objectives and his long-term vision. Moreover, he needs to be convinced and convincing about the scope of his project and its impact on the local community.

The ability of the project manager to manage the multitude of donors was also emerged from our exploratory study as a key success factor. The majority of interviewees reported that one of the difficulties which may hinder the project management process is the management of the multitude of donors. This is because most of the rural communities in Taroudant province are poor communes whose financial budget is very limited, which requires the use of multiple donors in order to implement their projects. Having a good knowledge of the procedures, requirements and funding rules is essential to avoid financing problems that may prevent the project realization.

It was also reported also in the interviewee's comments that project implementation success requires the project manager to have a strategic development vision for the long term.

Having the visibility of project impacts on the local community over the long term, might ensure stakeholders commitment to the project and increase the chance for the project management success.

The perseverance of the project manager was reported by the interviewees as an important element which contributes to project management success. It allows him to overcome all the challenges facing him during the project implementation process. 


\section{Factors related to the project team members}

One of the most critical factors for the successful implementation of projects is the possession of the project team members the necessary technical and administrative skills. This element was considered to be essential in all project implementation phases.

Simard (2008), Pinto and Slevin (1988), Khang and Moe (2008), Belassi and Tukel (1996), Al-Mashari and Zairi (1999), Hyvari (2006), Munns and Bjeirmi (1996) research have confirmed that the project team experience, qualification and skills are fundamental elements to the project implementation success.

The motivation of the project team members has also been identified as an element contributing to the project implementation success. According to the interviewee's comments, the motivation has a positive impact on the project implementation process. It allows creating a favorable environment, and promotes the team members commitment.

However, the explanations provided by various interviewees alluded to the existence of other factors related to the team member's project that must be considered.

The interviewees put an emphasis on the perfect knowledge of the project by the team members. They should know clearly the project objectives, and its long-term vision in promoting the local development. Also, the existence of synergy between the different members is identified as an element which can contribute to manage the project successfully. According to the interviewees' reports, the existence of this synergy among the project team creates a dynamic and favorable environment, where everyone cooperates and contributes to the project management success.

\section{Factors related to the organization}

In terms of organization factors, all interviewees attached great importance to the participation and effective involvement of stakeholders in project implementation process.

The stakeholders participation and involvement from the beginning of the project management process, can offer them the opportunity to share and exchange their own vision of development. It also allows, to ensure their most important needs and aspiration that are really taken into account in the decision making process.

The researches of The Pinto and Slevin (1988), Pinto and Prescott (1988), Simard (2008), Conyers and Kaul (1990), and Kwak (2002) attached a great importance to this factor, particularly in the first phase of project implementation process.

It was also suggested by the interviewees to have an external expert who can be an important factor to ensure the effectiveness of project management process. It may be an advisable thought in all its phases. This finding may be explained by the fact that local skills are limited and do not have the required technical and administrative skills for local project development implementation. Involving external expertise can have a tremendous impact on transferring knowledge and experience in order to improve the project management process. The importance of this factor to promote a successful project implementation has also been shown by researchers Pinto and Slevin (1988), Al-Mashari and Zairi (1999), and Struyk (2007).

Detailed planning of the project activities was suggested by the interviewees as a vital element in the project management process, especially in the planning and implementation phases. It can reduce the likelihood of encountering implementation problems.

This finding is similar to the assertions of Pinto and Slevin (1988), Pinto and Prescott (1988), Murphy and Ledwith (2007) and Al-Mashari and Zairi (1999). They consider careful planning of all project activities is a factor of its implementation success. 
Identifying those stakeholders directly and indirectly affected by the project has been raised by the interviewees as an important element that contributes to the project implementation success. The most important reason for identifying and understanding stakeholders is that it allows influencing the decision-making, and ensures a high level of commitment to the project. Research by Turner (1999) also reported the importance of this element as a necessary condition to the project management success.

Besides, the study indicates the importance of human and financial resources mobilization in the project management process. It is necessary for carrying out the project activities and contributing to their achievement of project objectives which have been assigned. The availability of human and financial resources is judged important in all project lifecycle phases.

The results of this exploratory study also puts into perspective the importance of taking into account values, attitudes, behaviors, beliefs and others share about the local population in the project implementation process. It is an important element which allows understanding the social organizations of a local community. These are the cultural mechanisms within which community life grows and community decisions are made.

Community culture contributes to a high degree of stakeholders' commitment to the goals and objectives of the project, and enhances the chances of project implementation success. The importance of this factor has also been indicated by researchers like Simard (2008), Conyers and Kaul (1990), Al-Mashari and Zairi (1999), and Kwak (2002). From this perspective, Muriithi and Crawford (2003) research has also identified the importance that community culture can play in project development success. According to these authors, one of the major reasons why development projects implemented in African countries fail due to the inadequacy and unsuitability of tools and management techniques implemented to local realities and cultures.
The local and provincial communal structures support is identified by the interviewees as an essential element to the project implementation success. Its importance consists of delivering the necessary services and resources to implement the project. Without this support the project tends to have difficulties which may hinder its execution. Research by Struyk (2007) demonstrates the importance of this element in the project implementation success.

A structured communication system between the various project stakeholders is also considered by the different interviewees as an important element contributing to the project implementation success. It allows exchanging the projectspecific information (progress, achievements, and difficulties) during the project lifecycle phases. The communication should be reciprocal between the project stakeholders as it minimizes conflicts and resolve issues. It provides the basis for the project stakeholders to work together and understand objectives and tasks to be completed.

Effective communication means better performance. The research work of Pinto and Slevin (1988), Belout and Gauvreau (2004), Muriithi and Crawford (2003), Diallo and Thuillier (2005) Hyvari (2006) and Al-Mashari and Zairi (1999), affirmed that the vital importance of the effective communication system among stakeholders contributes to the project implementation success.

However, the interviewees agreed to the existence of other factors contributing to the project implementation success. Indeed, the latter considered the role of risk management in promoting the project implementation success. An effective process to manage the potential risks by identifying, analyzing and addressing them can help reduce the negative impact and emerging opportunities.

Besides, the coherence in the way of where the project owner outsources the management of the project to another 
party is judged as an important success factor. This coherence will avoid potential conflicts of interest that may arise between the project owner and the manager.

Also a rigorous monitoring of project lifecycle phases by a steering committee made up of all project stakeholders is considered to be an important element. The practice of monitoring will ensure that everything is in compliance as it is expected to ensure proper conduct of the management process.

\section{Factors related to the project}

Project characteristics have been considered one of the essential dimensions of project management success as indicated by Belassi and Tukel (1996).

In fact, all interviewees attached great importance to the existence of an institutional and organizational framework for local development project implementation. It is chosen as a key success factor for an effective project management. The existence of this framework allows the local community to benefit from the administrative, technical and financial support offered by the local and regional institutions and ensures the partners commitment.

Ownership of population and local players to their project is indicated as an essential factor contributing to the project implementation success. According to interviewees, the collective consciousnesses of a common and shared responsibility lead to concerted decisions and strengthen the sense of territoriality.

However, our exploratory study reported the existence of other factors that could contribute to project management success. The absence of political considerations is judged as an essential factor, which has an important contribution in project management success. All interviewees emphasized that the integration of political considerations in the project management process leads to failure. And it can be a source of conflict of interest between the different parties involved in the project. Taking into account this dimension is to respond to the specific needs of a welldefined population, driven and willing to have projects and not to meet the needs and expectations of the general interest of the community. On the other hand, the interviewees considered good local governance as a KSF. It implies a system of democracy, which reflects a management system that is transparent and efficient.

\section{Factors related to the external environment}

The external environment of the project is also one of the factors influencing local development implementation success. Top management support is suggested as an important element for project management success. The interviewees attributed a great importance to this factor, as it helps provide the necessary skills and resources to implement the project activities. The importance of this element has been considered in Belout and Gauvreau (2004), Muriithi and Crawford (2003), Pinto and Slevin (1988b), Pinto and Prescott (1988), Belassi and Tukel (1996), Iyer and Jha (2005) and Hyvari (2006) researches as a necessary condition to promote project implementation success.

A clear understanding of the project environment from funding agencies was found by the interviewees as a factor which affects the project management success. The understanding of the external environment by donors ensures their commitment to fund the project in all its phases and contribute to the management process success. The importance of this element has also is been reported in the work of Khang and Moe (2008).

The interviewees value a trustful relationship with project beneficiaries as an important element that leads to project successful implementation. It allows ensuring the stakeholders commitment and creates the favorable conditions for project implementation. The importance of this factor was shown in the work of Simard (2008), Diallo and Thuillier (2005).

Also, the strategic vision of the project should be coherent with the national and 
regional development strategy, to ensure implementation success through which they are supported.

Interviewees raised the existence of other factors that contribute to the project management success. Thus, the success of a similar project in other jurisdictions is judged as success factor. Comparison between similar projects, which are implemented in different locations, may lead to ensure the beneficiaries participation and involvement in the project implementation process.

\section{Conclusion and Managerial Implications}

According to our analysis of the collected data, all interviewees share the same opinion, that the KSF identified by Muriithi and Crawford (2002), Simard (2008),

\section{References}

1. Al-Mashari, M and Zairi, M. (1999), 'BPR implementation process: an analysis of key success and failure factors,' Business Process Management Journal 5(1), 87-112.

2. Atkinson, R. (1999) 'Project management: cost, time and quality, two best guesses and a phenomenon, its time to accept other success criteria,' International journal of project management, 17(6), 337342.

3. Baccarini, D. (1999) 'The logical framework method for defining project success,' Project Management Journal, 30, 25-32.

4. Belassi, W and Tukel, O. I. (1996), 'A new framework for determining critical success/failure factors in projects,' International journal of project management, 14(3), 141-151.

5. Belout, A and Gauvreau, C. (2004), 'Factors influencing project success: the impact of human resource management,' International journal of project management 22(1), 1-11.

6. Bérubé, J and Noël, M. X. (2011), 'Petites entreprises de services et gestion de projet: à quoitient le succès?,' Journal of
Khang and Moe (2008), and DGCL (2008) are important for the local development project management success. They affect the project implementation process and contribute to its success. It was argued that their absence may cause project failure.

It should be noted that the degree of importance of these factors varies from one phase to another. Where some factors have a significant impact throughout the project life cycle, others have a significant impact only on certain phases.

\section{Acknowledgment}

We would like to thank all interviewees who contributed their valuable time and useful information to this study.

Small Business \& Entrepreneurship 24(4), 531-549.

7. Bourdon, I and Kimble, C. (2008), 'An Analysis of Key Factors for the Success of the Communal Management of Knowledge'. Proceedings of 13th UKAIS Conference, Bournemouth.

8. Clarke, A. (1999) 'A practical use of key success factors to improve the effectiveness of project management,' International journal of project management, 17(3), 139-145.

9. Conyers, D and Kaul, M. (1990), 'Strategic issues in development management: Learning from successful experience,' Public Administration and Development 10(2), 127-140.

10. Cooke-Davies, T. (2002) 'The real success factors on projects,' International journal of project management, 20(3), 185190.

11. DGCL. (2008). 'Projet de guide de l'élaboration $\mathrm{du}$ plan communal de développement (PCD) selon l'approche de planification stratégique participative' Royaume du Maroc, Ministère de l'intérieur, Direction générale des collectivités locales (DGCL) 
12. Diallo, A and Thuillier, D. (2005), 'The success of international development projects, trust and communication: an African perspective,' International journal of project management 23(3), 237-252.

13. Geoghegan, L and Dulewicz, V. (2008), 'Do project managers leadership competencies contribute to project success?,' Project Management Journal 39(4), 58-67.

14. Hyvari, I. (2006) 'Success of projects in different organizational conditions,' Project Management Journal, 37(4), 31.

15. Ika, LA. (2005a), 'Critères et Facteurs Clés de Succès des Projets' ASAC 2005 Conférence, Toronto, Ontario, 59-76.

16. Ika, LA. (2007) 'Les agences d'aide au développement font-elles assez en matière de formulation des facteurs clés de succès des projets?,' Management \& avenir, (2), 165-182.

17. Ika, LA. (2009) 'Project success as a topic in project management journalsm,' Project Management Journal, 40(4), 6-19.

18. Iyer, $\mathrm{K}$ and Jha, K. (2005), 'Factors affecting cost performance: evidence from Indian construction projects,' International journal of project management 23(4), 283295.

19. Jugdev, K and Muller, R. (2005), 'A retrospective look at our evolving understanding of project success,' Project Management Journal 36(4), 19-32.

20. Khang, DB and Moe, T. L. (2008), 'Success criteria and factors for international development projects: A life-cycle-based framework,' Project Management Journal 39(1), 72-84.

21. Kwak, Y. (2002), 'Critical success factors in international development project management' CIB 10th International Symposium Construction Innovation \& Global Competitiveness, Cincinnati, Ohio, 9-13 Septembre.

22. Legouté, J. R. (2001), 'Définir le développement: historique et dimensions d'un concept plurivoque' Economie Politique Internationale, Groupe de recherche sur l'intégration continentale, Université du Québec à Montréal.

23. Leidecker, JK and Bruno, AV. (1984), 'Identifying and using critical success factors,' Long range planning 17(1), 23-32.

24. Lim, C and Mohamed, MZ. (1999), 'Criteria of project success: an exploratory re-examination,' International journal of project management 17(4), 243-248.

25. Liu, AM and Walker, A. (1998), 'Evaluation of project outcomes,' Construction Management \& Economics 16(2), 209-219.

26. Miles, MB and Huberman, AM (2003) Analyse des données qualitatives, De Boeck Supérieur, $632 \mathrm{p}$.

27. Munns, A and Bjeirmi, BF. (1996), 'The role of project management in achieving project success,' International journal of project management 14(2), 81-87.

28. Muriithi, N and Crawford, L. (2003). 'Approaches to project management in Africa: implications for international development projects,' International journal of project management 21(5), 309319.

29. Murphy, A and Ledwith, A. (2007), 'Project management tools and techniques in high-technology SMEs,' Management Research News 30(2), 153-166.

30. Pakseresht, A and Asgari, G. (2012). 'Determining the Critical Success Factors in Construction Projects: AHP Approach,' Interdisciplinary Journal of Contemporary Research in Business 8 (4), 383-393.

31. Pecqueur, B. (2000) Le développement local: pour une économie des territoires, Paris, Syros Alternatives, $132 \mathrm{p}$.

32. Pecqueur, B. (2005) 'Le développement territorial une nouvelle approche des processus de développement pour les économies du Sud,' dans Benoît Antheaume, Frédéric Giraut, Le territoire est 
mort Vive les territoires, Paris, IRD Editions, 295-316.

33. Pinto, JK and Prescott, JE. (1988), 'Variations in critical success factors over the stages in the project life cycle,' Journal of management, 14(1), 5-18.

34. Pinto, JK and Slevin, DP. (1988), 'Critical Success Factors in Effective Project Implementation,' Project management handbook, 167-190.

35. Prabhakar, GP. (2008) 'What is Project Success: A Literature Review,' International Journal of Business and Management, 3(9), 3-10.

36. Shenhar, AJ., Levy, O. and Dvir, B. (1997), 'Mapping the dimensions of project success,' Project Management Journal, 28, 5-13.

37. Simard, M. (2008), 'la gestion de projet et la théorie du développement' Cahier de recherche exploratoire en management et en gestion de projet, 132-161.

38. Smith, C. P. (2000), 'Content analysis and narrative analysis' Handbook of research methods in social and personality psychology, 313-335.

39. Strauss, AL and Corbin, J. (1990) Basics of qualitative research: techniques and procedures for developing grounded t1heory: Sage publications Newbury Park, CA, $336 \mathrm{p}$.
40. Struyk, RJ. (2007) 'Factors in successful program implementation in Russia during the transition: pilot programs as a guide,' Public Administration and Development, 27(1), 63-83.

41. Tremblay, S. (1999), 'Du concept de développement au concept de l'aprèsdéveloppement: trajectoire et repères théoriques' Collection « travaux et études en développement régional », Université du Québec à Chicoutimi.

42. Turner, JR. (1999) The handbook of project-based management, McGraw-Hill London, 452 p.

43. Turner, JR. (2004) 'Five necessary conditions for project success,' International journal of project management, 22(5), 349-350.

44. Turner, JR and Müller, R. (2005), 'The project manager's leadership style as a success factor on projects: a literature review,' Project Management Journal 36(2), 49-61.

45. Valentin, M., Laura, B. and Delia, G. (2013), 'A pest-c multifactor analysis for human resources development project's implementation in public universities in Romania,' European International Journal of Science and Technology, 2(3), 141-154.

46. Westerveld, E. (2003) 'The Project Excellence Model: linking success criteria and critical success factors,' International journal of project management, 21(6), 411418. 


\section{IBIMA Publishing}

Journal of North African Research in Business

http://www.ibimapublishing.com/journals/JNARB/jnarb.html

Vol. 2015 (2015), Article ID 607790, 15 Pages

DOI: $10.5171 / 2015.607790$

Cite this Article as: Ouafa BARAKAT, Abdelaziz BENDOU and Juan Carlos MARTIN (2015), " Success Factors for Local Development Project Management Case of Taroudant Province - Morocco ", Journal of North African Research in Business, Vol. 2015 (2015), Article ID 607790, DOI: 10.5171/2015.607790 